\title{
Study of Effect of Various Grades of Exercise on Serum Proteins in Healthy Young Indian Adults
}

\author{
Tripti Tripathi ${ }^{1}$, Sonali Saxena ${ }^{2}$, Saurabh Saha ${ }^{3}$, Jalaj Saxena ${ }^{4}$, \\ Dolly Rastogi $^{5}$, Chitra Srivastava ${ }^{6}$, Preeti Kanowjia ${ }^{7}$ \\ ${ }^{1}$ Assistant Professor (Physiology), ${ }^{2}$ Associate Professor (Medicine), ${ }^{3}$ Associate Professor (Physiology), \\ ${ }^{4}$ Professor \& Head (Physiology), ${ }^{5}$ Professor (Physiology), ${ }^{6}$ Associate Professor (Physiology), ${ }^{7}$ Assistant Professor \\ (Physiology), Department of Physiology, G.S.V.M. Medical College, Kanpur
}

\begin{abstract}
Serum total protein levels changes occur as a result of various grades of exercise intensity. The main objective of this study was to evaluate the effect of different grades of exercise on the serum levels of proteins in healthy young Indian adults. Fifty six healthy students (28 each, male and female) with an age range of 18-27 years were subjects in this study. The participants performed an exercise test of moderate to vigorous intensity on bicycle ergometer. The serum concentrations of total serum proteins were measured by colorimetric method. The results show significantlysignificantly different and lower (9.9\%) total serum protein level after moderate exercise $(7.10 \pm 0.18$ vs. $6.40 \pm 0.14$, mean difference $=0.70, q=4.78, p<0.01)$ and higher $(7.9 \%)$ after severe exercise $(7.10 \pm 0.18$ vs. $7.72 \pm 0.12$, mean difference $=0.61, q=4.18, p<0.05)$ as compared to baseline was observed. Further, the mean total serum protein level also increases $(17.0 \%)$ significantly after severe exercise as compared to after moderate exercise ( $6.40 \pm 0.14 \mathrm{vs.} 7.72 \pm 0.12$, mean difference $=1.31, \mathrm{q}=8.96, \mathrm{p}<0.001)$. These results support the different grades of exercise affect serum total proteins.
\end{abstract}

Keywords: Exercise, Serum Protein, Ergometer, Endurance.

\section{Introduction}

Impact of physical activity and exercise on human population, focusing mainly on health benefits, have gained much attention since long back. It is well established that physical exercise can provoke large and diverse changes in the concentration of many biochemical parameters from resting levels Kim DY et al $(2014)^{[1]}$.

Physical exercise generally delays aging, strengthens muscles improves cardiovascular health, helps in weight

\section{Corresponding Author: \\ Dr. Saurabh Saha}

Associate Professor, Department of Physiology, G.S.V.M. Medical College, Kanpur

e-mail:drsahagsvm@gmail.com loss and boost the immune system. Physical exercise is also known to prevent many "diseases of affluence" such as coronary artery disease, type 2 diabetes mellitus and obesity Kim DY et al (2014) ${ }^{[1]}$. Proteins are used as auxiliary fuels during muscular work and few stored amino acids are linked with fats and form lipoproteins. The tissue proteins are broken down to amino acids in order to get energy but the amino acids liberated in the process are not used as fuels instead they are stored in blood as protein during exercise. Serum proteins, present in blood plasma serve many other functions, including transport of lipids, hormones, vitamins and minerals in the circulatory system and the regulation of a cellular activity and functioning of the immune system. Many blood proteins act as enzymes, complement components, protease inhibitors or kinin precursors. The total protein consists of two major groups of proteins: albumin and globulin. Serum albumin accounts for $55 \%$ of blood proteins, and is a major contributor to maintaining the osmotic pressure of plasma to assist in 
the transport of lipids and steroid hormones. Globulins make up $38 \%$ of blood proteins and transport ions, hormones, and lipids assisting in immune function. Fibrinogen comprises $7 \%$ of blood proteins; conversion of fibrinogen to insoluble fibrin is essential for blood clotting. The remainder of the plasma proteins $(1 \%)$ is regulatory proteins, such as enzymes, pro-enzymes, and hormones. All blood proteins are synthesized in liver except for the gamma globulins. The specific blood proteins include: Prealbumin (transthyretin), Alpha 1 antitrypsin (neutralizes trypsin that has leaked from the digestive system), Alpha 1 acid glycoprotein, Alpha 1 fetoprotein, alpha2-macroglobulin, Gamma globulins, Beta-2 microglobulin, Haptoglobin, Ceruloplasmin, Complement component 3, Complement, component 4, C-reactive protein (CRP), Lipoproteins (chylomicrons, VLDL, LDL, HDL), Transferrin, Prothrombin and MBL or MBP.It is also reported that acute exercise may induce high levels of salivary cortisol, TNF-alpha and nitric oxide. Muscle protein synthesis is regulated by two main anabolic stimuli, food intake and physical activity. The dietary protein derived amino acids act as key signaling proteins activating anabolic pathways in skeletal muscle tissue and provide building blocks for muscle protein synthesis. Ingestion of meal protein elevates muscle protein synthesis rates for $2-5 \mathrm{~h}$ following meal ingestion. Differential stimulation of myofibrillar and sarcoplasmic protein synthesis on protein ingestion at rest and after resistance exercise has been reportedby Moore DR et al (2009) $)^{[2]}$. The physical exercise directly stimulates skeletal muscle protein synthesis, and has been shown to persist for up to $24 \mathrm{~h}$ after cessation of exercise in young men as seen by Burd NA et al (1997) ${ }^{[3]}$. Different types of exercise will stimulate the synthesis of different sets of proteins. Whereas Kylasov AF et al (2011) ${ }^{[4]}$ found that resistance type exercise strongly stimulates the synthesis of muscle contractile (myofibrillar) proteins, endurance type exercise will have a greater impact on stimulating the synthesis of mitochondrial proteins, thereby allowing exercise-specific muscle adaptation. Regular and moderate exercise has favourable effects on the immune system by increasing immunoglobulins which are potent protective factors as observed by Karacabey $\mathrm{K}$ et al (2005) ${ }^{[5]}$. In prolonged exercising subjects albumin level is significantly raised and the raised albumin in serum is important as it may scavenge reactive oxygen species generated during exercises was found by both Brzeszczynska $J$ et al (2008) ${ }^{[6]}$ and Malatesta $\mathrm{D}$ et al (2009) ${ }^{[7]}$. In vigorously exercising subjects compared with the controlsincreased levels of aspartate transaminase (AST), total protein (TP), albumin, urea and high density lipoprotein-cholesterol (HDL-C) were observed while the levels of $\mathrm{Na}+, \mathrm{K}+$, cholesterol (TC), triglycerides (TG), low density lipoprotein-cholesterol (LDL-C) and glucose were significantly reduced as found byJohnson JL et al (2007) ${ }^{[8]}$. The level of proteins that differ between groups indicate a long-term exercise effect on plasma protein concentrations was a important finding of Schild M et al (2016) ${ }^{[9]}$.Sedgwick MJet al $(2016)^{[10]}$ observed that acute bout of high-intensity interval rowing increased plasma thrombin generation immediately after exercise, but these differences were eliminated 16-24 $\mathrm{h}$ after exercise.

\section{Materials and Method}

The present study was carried out on 56 Subjects, 28 males and 28 female students of 18 to 27 years age of $1^{\text {st }}$ year M.B.B.S. in the Department of Physiology, G.S.V.M. Medical College, Kanpur. The subjects were told about the study and their written consent was taken.A working proforma was asked to be filled by every subject which consisted of Name, Age, Sex, Occupation, Address, history of physical exercise,Addiction, Drug History, Personal or family history of Diabetes, Hypertension and Heart Disease and also history of any chronic disease. Subjects with the history of any chronic disease, endocrinopathy or subjects taking steroidal hormonal drug (exogenous testosterone or steroid), alcoholics, smokers, sportsperson and athletes were excluded from the study. All physical parameters like age (years), Height (cms), Weight (Kgs) and blood pressure $(\mathrm{mm} \mathrm{Hg})$ were recorded initially in all subjects. The subjects were divided into two groups after defining their body mass index (BMI) and classified as non-obese group with $\mathrm{BMI}<25 \mathrm{~kg} / \mathrm{m}^{2}$ and obese group with BMI $\geq 25 \mathrm{~kg} / \mathrm{m}^{2}$.

After measurements the subjects were instructed to warm-up on the cycle ergometer for 5 minutes at a very light workload. At this time, the seat height was adjusted to the optimal height and comfort. The light warms up was followed up by 5 minutes of stretching,primarily emphasizing the torso and the lower extremities.Subject was subsequently properly fit with a mouthpiece and oxygen uptake which was used to make sure that the values were normal and the metabolic system was functioning properly. The incremental exercise test began at a workload previously determined by the subjectstraining history and any previous VO2 max data results reported by the subject. The workload increased at 
the end of the 3 minute intervals (stages) until volitional fatigue. The target of the exercise was to achieve a heart rate 125-130 beats/minute (severe exercise) and it was achieved in 10 to 15 minutes by doing the cycling without any extra load. The brink of exhaustion after 10 minutes of exercise was taken as end point of the exercise for that subject. The baseline readings of total serum total protein were taken before exercise. The subjects were then asked to do various grades of exercise on the alternate day basis under supervision. Total serum proteins were then measured after exercise period ended. The $20 \%$ differences in the intensities of each of the exercise trials were chosen to prevent any potential overlap in workloads within each subject's exercise trials. The workload was set beforehand, but was occasionally adjusted after the protocol was initiated based on the subjects' metabolic responses. The reported workloads were mean values calculated over the duration of the 30 minutes of exercise. Collection and storage of blood sample was done as the first blood samples $(3 \mathrm{~mL})$ as baseline, after placement of a catheter, were collected using a 3-cc syringe and a 25 gauge needle in the morning between 9 a.m.- 2.00 p.m. at the Department of Physiology, G.S.V.M Medical College, Kanpur. All samples were immediately transferred into a sterile vial (Vaccutainer) and allowed to clot. The blood samples were then spun at $3000 \mathrm{rpm}$ and $4{ }^{\circ} \mathrm{C}$ using a refrigerated centrifuge to separate the serum. The plasma was pipetted into cryo-freeze tubes and stored at $-80^{\circ} \mathrm{C}$ degrees Celsius in an ultra freezer. After the blood sample was taken, subjects were allowed to actively cool down on the cycle ergometer, followed by a resting period. After 30 minutes recovery post-exercise, moderate and severe exercise were done by subjects with Heart rate (HR) reaching $>25 \pm 50 \%$ and $>50 \%$ respectively of the baseline HR. Then last blood samples were collected. These four trials were randomized and separated by a minimum of 72 hours. Estimation of total serum proteins was done by the stored serum.

Statistical analysis of groups was compared by independent Student's t test. Continuous groups were also compared by repeated measures one way analysis of variance (ANOVA) and the significance of mean difference between the groups was done by Tukey's HSD (honestly significant difference) post hoc test after ascertaining normality by Shapiro-Wilk's test and homogeneity of variance by Levene's test. Pearson correlation analysis and simple linear regression analysis were done to assess association and strength of association between the variables respectively.

A two-tailed $(\alpha=2) \mathrm{p}$ value less than $0.05(\mathrm{p}<0.05)$ was considered statistically significant. Analyses were performed on SPSS software (windows version 17.0).

\section{Observations and Results}

The age of subjects ranged from 18-27 yrs with mean ( \pm SE) $19.59 \pm 0.19$ yrs and median 19 yrs. The most of the subjects were $\leq 20$ yrs $(83.9 \%)$. Further, among subjects, 28 (50.0\%) were females and $28(50.0 \%)$ were males. The height, weight and BMI of subjects ranged from $141-183 \mathrm{~cm}, 39-94 \mathrm{~kg}$ and $18-30 \mathrm{~kg} / \mathrm{m}^{2}$ respectively with mean $( \pm \mathrm{SE}) 163.29 \pm 1.49 \mathrm{~cm}, 60.10 \pm 1.47 \mathrm{~kg}$ and $22.45 \pm 0.38 \mathrm{~kg} / \mathrm{m}^{2}$ respectively and median $162 \mathrm{~cm}, 60$ $\mathrm{kg}$ and $22 \mathrm{~kg} / \mathrm{m}^{2}$ respectively. The height, weight and BMI of most the subjects were $\leq 165 \mathrm{~cm}(57.1 \%), \leq 60 \mathrm{~kg}$ $(53.6 \%)$ and $\leq 25 \mathrm{~kg} / \mathrm{m}^{2}(85.7 \%)$ respectively. The SBP and DBP of subjects ranged from 94-154 mmHg and 64$104 \mathrm{mmHg}$ respectively with mean $( \pm \mathrm{SE}) 114.93 \pm 1.74$ $\mathrm{mmHg}$ and $77.38 \pm 1.23 \mathrm{mmHg}$ respectively and median $112 \mathrm{mmHg}$ and $80 \mathrm{mmHg}$ respectively. The SBP and DBP of most the subjects were $\leq 120 \mathrm{mmHg}(78.6 \%)$ and $\leq 80 \mathrm{mmHg}(78.6 \%)$ respectively i.e. mostly within normal range.

The mean total serum protein decreased after moderate exercise while increased after severe exercise as compared to baseline. Comparing the mean total serum protein level of three group/periods, ANOVA showed significantly different total serum protein level among the groups $(\mathrm{F}=20.12, \mathrm{p}<0.001)$.

\section{Table 1: Association between basic characteristics and outcome measures after moderate exercise $(n=56)$}

\begin{tabular}{|l|c|c|c|}
\hline Basic characteristics & N & Mean \pm SE & p-value \\
\hline $\begin{array}{l}\text { Age }(\mathrm{yrs}): \\
\leq 20\end{array}$ & 47 & $6.49 \pm 0.16$ & \\
$>20$ & 9 & $5.96 \pm 0.26$ & 0.161 \\
\hline Sex : & & & \\
Female & 28 & $6.79 \pm 0.17$ & 0.004 \\
Male & 28 & $6.01 \pm 0.19$ & \\
\hline Height $(\mathrm{cm}):$ & & & \\
$\leq 165$ & 32 & $6.71 \pm 0.18$ & 0.009 \\
$>165$ & 24 & $5.99 \pm 0.19$ & \\
\hline Weight $(\mathrm{kg}):$ & & & \\
$\leq 60$ & 30 & $6.69 \pm 0.18$ & 0.028 \\
$>60$ & 26 & $6.08 \pm 0.20$ & \\
\hline
\end{tabular}




\begin{tabular}{|l|c|c|c|}
\hline Basic characteristics & N & Mean \pm SE & p-value \\
\hline BMI $\left(\mathrm{kg} / \mathrm{m}^{2}\right):$ & 48 & $6.34 \pm 0.15$ & \\
$<25$ & 8 & $6.79 \pm 0.39$ & 0.264 \\
$\geq 25$ & & & \\
\hline SBP $(\mathrm{mmHg}):$ & 44 & $6.53 \pm 0.16$ & 0.072 \\
$\leq 120$ & 12 & $5.93 \pm 0.24$ & \\
$>120$ & & & \\
\hline DBP $(\mathrm{mmHg}):$ & 44 & $6.52 \pm 0.15$ & 0.102 \\
$\leq 80$ & 12 & $5.97 \pm 0.31$ & \\
$>80$ & \multicolumn{3}{|l}{} \\
\hline
\end{tabular}

Further, the mean total serum protein levels over the periods were also compared according to gender. The mean total serum protein in females decreased after moderate exercise while it reached almost similar level as of baseline after severe exercise. In contrast, in males, it also decreased after moderate exercise but increased after severe exercise.

Comparing the mean total serum protein levels between the periods, Student ' $t$ ' test and Tukey test showed similar $(\mathrm{p}>0.05)$ total serum protein level between the periods in females. In contrast, in males, it decreased significantly $(\mathrm{p}<0.001)$ after severe exercise as compared to baseline. Further, in males, it increased significantly $(\mathrm{p}<0.001)$ after severe exercise as compared to moderate exercise. Comparing the mean total serum protein level between the genders, Student ' $t$ ' test and Tukey test showed similar $(\mathrm{p}>0.05)$ total serum protein level between the genders at all periods.

Table 2: Association between basic characteristics and outcome measures after severe exercise $(n=56)$

\begin{tabular}{|l|c|c|c|}
\hline Basic characteristics & N & Mean \pm SE & p value \\
\hline Age $(\mathrm{yrs}):$ & 47 & $7.69 \pm 0.14$ & \\
$\leq 20$ & 9 & $7.83 \pm 0.23$ & 0.671 \\
$>20$ & 28 & $7.48 \pm 0.13$ & \\
\hline Sex $:$ & 28 & $7.96 \pm 0.19$ & 0.042 \\
Female & & & \\
Male & 32 & $7.60 \pm 0.15$ & 0.264 \\
\hline Height $(\mathrm{cm}):$ & 24 & $7.87 \pm 0.19$ & \\
$\leq 165$ & & & \\
$>165$ & 30 & $7.52 \pm 0.12$ & 0.082 \\
\hline Weight $(\mathrm{kg}):$ & 26 & $7.94 \pm 0.21$ & \\
$\leq 60$ & & & \\
$>60$ & 48 & $7.68 \pm 0.13$ & 0.403 \\
\hline BMI $\left(\mathrm{kg} / \mathrm{m}^{2}\right):$ & 8 & $7.96 \pm 0.27$ & \\
$\leq 25$ & &
\end{tabular}

\begin{tabular}{|l|c|c|c|}
\hline Basic characteristics & N & Mean \pm SE & p value \\
\hline SBP (mmHg) : & & & \\
$\leq 120$ & 44 & $7.64 \pm 0.13$ & 0.216 \\
$>120$ & 12 & $8.00 \pm 0.29$ & \\
\hline DBP (mmHg) : & & & \\
$\leq 80$ & 44 & $7.54 \pm 0.11$ & 0.004 \\
$>80$ & 12 & $8.36 \pm 0.34$ & \\
\hline
\end{tabular}

To assess the influence of basic characteristics (age, sex, height, weight, BMI, SBP and DBP) on outcome measures (heart rate, serum cortisol level and total serum protein level), the Pearson correlation analysis was done. The heart rate did not correlate significantly $(\mathrm{p}>0.05)$ with any of the basic characteristics indicating that heart rate did not associate to basic characteristics either at pre exercise or post exercise (moderate and severe).

At moderate exercise, total serum protein level showed significant $(\mathrm{p}<0.05$ or $\mathrm{p}<0.01)$ and negative (inverse) correlation with both sex and height but significant and positive correlation with sex, weight and DBP at severe exercise indicating that total serum protein level inversely associated to sex and height during moderate exercise while directly associated to sex, BMI and DBP during severe exercise. The mean total serum protein was found significantly $(\mathrm{p}<0.05)$ different and higher in females as compared to males. For Moderate exercise, the association between basic characteristics and outcome measures (HR, serum total serum protein concentrations) after moderate exercise. The all outcome measures were found significantly associated to sex. Further, total serum protein was found significantly associated to height. Moreover, total serum protein was also found to be associated with weight.

Table 5: For each gender, comparison ( $p$ value) of mean total serum protein level between the periods by Student ' $t$ ' test and Tukey test

\begin{tabular}{|l|c|c|}
\hline Groups/Periods & Mean \pm SE $(\mathbf{n}=\mathbf{5 6})$ & p-value \\
\hline Baseline & $7.10 \pm 0.18$ & \multirow{2}{*}{$<0.001$} \\
\cline { 1 - 2 } After moderate exercise & $6.40 \pm 0.14$ & \\
\cline { 1 - 2 } After severe exercise & $7.72 \pm 0.12$ & \\
\hline
\end{tabular}

Table 3: Pre and post exercise total serum protein concentration $(\mathrm{g} / \mathrm{dL})$ of subjects

\begin{tabular}{|l|c|c|}
\hline Comparison & Female & Male \\
\hline Baseline vs. After moderate exercise & 0.110 & 0.074 \\
\hline Baseline after severe exercise & 1.000 & $<0.001$ \\
\hline $\begin{array}{l}\text { After moderate exercise vs. After severe } \\
\text { exercise }\end{array}$ & 0.106 & $<0.001$ \\
\hline
\end{tabular}


For Severe exercise, the total serum protein was found significantly associated to sex and DBP.

Table 4: For each gender, comparison (p value) of mean total serum protein level between the periods by Student ' $t$ ' test and Tukey test.

\begin{tabular}{|l|c|c|}
\hline Comparison & Female & Male \\
\hline Baseline vs. After moderate exercise & 0.110 & 0.074 \\
\hline Baseline after severe exercise & 1.000 & $<0.001$ \\
\hline $\begin{array}{l}\text { After moderate exercise vs. } \\
\text { After severe exercise }\end{array}$ & 0.106 & $<0.001$ \\
\hline
\end{tabular}

Table 6: Correlation ( $r$ value) between basic characteristics and outcome measures at three different periods $(n=56)$

\begin{tabular}{|l|c|c|c|}
\hline \multirow{2}{*}{$\begin{array}{l}\text { Basic } \\
\text { characteristics }\end{array}$} & \multicolumn{3}{|c|}{ Total serumprotein concentration (g/dL) } \\
\cline { 2 - 4 } & Baseline & $\begin{array}{c}\text { Moderate } \\
\text { exercise }\end{array}$ & $\begin{array}{c}\text { Severe } \\
\text { exercise }\end{array}$ \\
\hline Age $(\mathrm{yrs})$ & $-0.17^{\text {ns }}$ & $-0.21^{\text {ns }}$ & $0.07^{\text {ns }}$ \\
\hline Sex & $-0.28^{*}$ & $-0.38^{* *}$ & $0.27^{*}$ \\
\hline Height $(\mathrm{cm})$ & $-0.15^{\text {ns }}$ & $-0.31^{*}$ & $0.21^{\text {ns }}$ \\
\hline Weight $(\mathrm{kg})$ & $-0.04^{\text {ns }}$ & $-0.22^{\text {ns }}$ & $0.27^{*}$ \\
\hline BMI $\left(\mathrm{kg} / \mathrm{m}^{2}\right)$ & $0.08^{\text {ns }}$ & $0.04^{\text {ns }}$ & $0.16^{\text {ns }}$ \\
\hline SBP $(\mathrm{mmHg})$ & $-0.11^{\text {ns }}$ & $-0.14^{\text {ns }}$ & $0.10^{\text {ns }}$ \\
\hline DBP $(\mathrm{mmHg})$ & $-0.05^{\text {ns }}$ & $-0.15^{\text {ns }}$ & $0.38^{* *}$ \\
\hline
\end{tabular}

ns- $\mathrm{p}>0.05,{ }^{*}$ - $<<0.05, * *_{-} \mathrm{p}<0.01, * * *_{-} \mathrm{p}<0.001$

\section{Discussion}

Physical exercise is undoubtedly a proven stimulus to the secretion of many hormones including cortisol playing an important role in the synthesis of amino acids and proteins. It affects the metabolism of several proteins crucial to human life. The demographic profile of all the subjects was comparable as all the 56 subjects belonged to the same race and were of comparable age group.

The mean total serum protein decrease after moderate exercise while increase after severe exercise as compared to baseline. Comparing the mean total serum protein level of three group/periods, ANOVA showed significantly different total serum protein level among the groups $(\mathrm{F}=20.12, \mathrm{p}<0.001)$.

While comparing, the mean total serum protein level between the groups, Student ' $t$ ' test and Tukey test showed significantly different and lower $(9.9 \%)$ total serum protein level after moderate exercise $(\mathrm{p}<0.01)$ and higher $(7.9 \%)$ at after severe exercise $(\mathrm{p}<0.05)$ as compared to baseline. Further, the mean total serum protein level also increase $(17.0 \%)$ significantly at after severe exercise as compared to at after moderate exercise $(p<0.001)$. The level of endurance changes with the serum protein levels of test subjects.

There are potential limitations and confounding factors in this investigation which may have impacted the results and potentially limit the reliability and validity of the findings. First, some subjects completed their trials in the morning while others completed their trials in the afternoon, potentially causing differing responses between subjects; although, each respective subject did consistently replicate the time of day for each of their trials. Second, it was relied on the truthfulness of the subjects in providing background information and adhering to experimental compliance procedures, including: medical information, training history, dietary records, acute training (no strenuous exercise in the 24 hours prior to the trials), diet (4 hours post prandial, and no alcohol, NSAIDs, or caffeine in the previous 8 hours). There is either a delay in muscle protein release by damaged muscle fibers, or the proteins are unable to leave the interstitial area for the 24 to 48 hour period after exercise. Because of the long delay, care should be taken when blood protein levels are interpreted in persons who have exercised strenuously (even if only for a short period of intense effort) several days before any diagnostic tests are performed.

Inaccuracies in the information and/or procedures may have introduced systematic error into the study and confounded outcomes. The collection of samples of serum may have also introduced error into study. The drawback of blood sampling is that venipuncture can elicit stressful responses that could lead to rapidly elevated blood cortisol levels. This 'white-coat' effect cannot be disregarded if testing is carried out, where personnel are unfamiliar both the testing situation and situations where subjects remain in anticipation of the venipuncture. Although in the present study, subjects rested for 30 minutes before the first blood sample was taken as well as experienced the procedure on four separate occasions, which might have mitigated some of this effect.

We have tried to control all of these factors through sufficient planning, dialogue with the subjects, and collection in controlled environment; nonetheless, errors and oversights may still have occurred. Thus, according to our study, there is correlation of the serum cortisol 
levels and the serum total protein according to the grades of exercise but still larger and long-term studies are needed to establish this association.

Similar to our study, Moderate exercise does not alter the total protein level while other serum proteins are decreased, is also reportedAdedapo KS et al (2009) ${ }^{[11]}$.

However Nosaka K et al (1997) $)^{[12]}$ have also noticed the increase in serum total protein after vigorous exercise. The increase in level of serum protein after vigorous exercise as our results indicate

\section{Conclusion}

The serum protein level also decreased after moderate exercise both in males and females but increased in males after severe exercise while no significant change in serum protein in females was observed after severe exercise. The mean total serum protein was significantly higher in lower height and lower weight as compared to higher height $(>165 \mathrm{~cm})$ and higher weight $(>60 \mathrm{~kg})$. More research is needed for better understanding of serum protein in different time periods (for example, one hour, four hours, and 48 hours after exercise) to measure possible changes following acute combination exercise. Thus, according to our study, there is correlation of the serum total protein according to the grades of exercise but still larger and long-term studies are needed to establish this association.

\section{Conflict of Interest: Nil}

\section{Source of Funding: Self}

Ethical Clearance: Given by Institutional Ethics Committee of the college.

\section{References}

1. Kim DY, Jung SY, Seo BD: Effect of exercise intervention on changes in free Fatty Acid levels and metabolic risk factors in stroke patients. J Phys TherSci, 2014; 26: 275-279.

2. Moore DR, Tang JE, Burd NA, Rerecich T, Tarnopolsky M, Phillips SM. Differential stimulation of myofibrillar and sarcoplasmic protein synthesis with protein ingestion at rest and after resistance exercise. J. Physiol. 2009; 587: 897-904.
3. Burd NA, West DW, Moore DR, Atherton PJ, Staples AW, Prior T, Tang JE. Enhanced amino acid sensitivity of myofibrillar protein synthesis persists for up to $24 \mathrm{~h}$ after resistance exercise in young men. J. Nutr. 2011; 141: 568-573.

4. Kylasov AF, Gavrov S. Diversity of Sport: non-destructive evaluation. Paris: UNESCO: Encyclopedia of Life Support Systems. 2011; 462491.

5. Karacabey K, Saygin O, Ozmerdivenli R, Zorba E, Godekmerdan A, Bulut V. The effects of exercise on the immune system and stress hormones in sportswomen. Neuro Endocrinol Lett.2005; 26(4): 361-6.

6. Brzeszczynska J, Pieniazek A, Gwozdzinski L, Gwozdzinski K, Jegier A. Structural alterations of erythrocyte membrane components induced by exhaustive exercise. Appl. PhysiolNutr. Metab.2008; 33(6): 1223-1231.

7. Malatesta D, Werlen C, Bulfar, S, Chenevière X, Borrani F. Effect of high-intensity interval exercise on lipid oxidation during post-exercise recovery. Med. Sci. Sports Exerc. 2009; 41(2): 364-374.

8. Johnson JL, Slentz CA, Houmard J. Exercise training amount and intensity effects on metabolic syndrome. Am J Cardiol. 2007; 100: 1759-1766.

9. Schild M, Eichner G, Beiter T, Zügel M, KrumholzWagner I, Hudemann J. Effects of Acute Endurance Exercise on Plasma Protein Profiles of EnduranceTrained and Untrained Individuals over Time. Mediators Inflamm.2016; 48: 519-35.

10. Sedgwick MJ, Thompson M, Garnham J, Thackray AE, Barrett LA, Powis M, Stensel DJ. Acute high-intensity interval rowing increases thrombin generation in healthy men. Eur J Appl Physiol.2016; 116(6): 1139-48.

11. Adedapo KS, Akinosun OM, Arinola GO, Odegbemi BO, Adedeji OI. Plasma Biochemical Changes During Moderate and Vigorous Exercises. International Journal of Sports Science and Engineering. 2009; 03: 073-076.

12. Nosaka K, Clarkson PM., Apple FS. Time course of serum protein changes after strenuous exercise of the forearm flexors. J Lab Clin Med.1992; 119: 183-8. 